\title{
Nummular headache after trans-sphenoidal surgery: a referred pain-based headache syndrome
}

\author{
Monetowy ból głowy po operacii z dostępu przezklinowego - zespół bólu głowy \\ wynikajq̨cy z rzutowania bólu
}

\author{
Hsin-Ling Yin', Chi Chui',3, Wai-Fai Tung4, Wei-Hsi Chen ${ }^{3,5}$ \\ IFaculty of Clinical Forensic Medicine, Department of Pathology, Kaohsiung Medical University Hospital and College of Medicine, Kaohsiung Medical University, Kaohsiung, Taiwan \\ ${ }^{2}$ Department of Neurosurgery, Paochien Hospital, Pingtung, Taiwan \\ ${ }^{3}$ Graduate Institute of Technology and Law, National First University of Science and Technology, Kaohsiung, Taiwan \\ ${ }^{4}$ Department of Neurology, Tungs' Taichung Metroharbor Hospital, Taichung, Taiwan \\ ${ }^{5}$ Department of Neurology, Kaohsiung Chang Gung Memorial Hospital and College of Medicine, Chang Gung University, Kaohsiung, Taiwan
}

Neurologia i Neurochirurgia Polska 2013; 47, 4: 398-401

DOI: 10.5114/ninp.2013.36764

\begin{abstract}
Nummular headache $(\mathrm{NH})$ is a newly categorized primary headache characterized by a consistent location, shape and size of painful area in each attack. The etiopathogenesis is entirely unknown. Currently, the peripheral theory of epicranial neuralgia is accepted more widely than the central theory but it cannot fully explain the clinical picture.

We report a patient who suffered from a relapsing and remitting course of $\mathrm{NH}$ at the high parietal area and vertex shortly after resection for pituitary prolactinoma via a trans-sphenoidal approach. There was no focal trophic change or paresthesia but a mild allodynia in the painful area. The patient did not exhibit trigeminal sensory disorder or cranial trauma thoroughly. The pain responded well to gabapentin. Therefore, physicians should be aware of postoperative $\mathrm{NH}$, which is amenable to treatment. The findings in our patient support a dual mechanism of $\mathrm{NH}$ and suggest that central $\mathrm{NH}$ is a form of referred pain.
\end{abstract}

Key words: nummular headache, postoperative headache, prolactinoma, trans-sphenoidal surgery.

\section{Streszczenie}

Monetowy ból głowy to nowo sklasyfikowany pierwotny ból głowy, który cechuje się spójnym umiejscowieniem, kształtem i rozmiarem obszaru objętego bólem w czasie każdego napadu. Etiopatogeneza schorzenia jest nieznana. Obecnie przyjmuje się raczej obwodową niż ośrodkową teorię nerwobólu w obrębie czaszki, ale nie tłumaczy ona w pełni obrazu klinicznego.

W pracy opisano chorego, który cierpiał na nawracający monetowy ból głowy umiejscowiony wysoko w okolicy ciemieniowej i na szczycie głowy. Dolegliwości rozpoczęły się wkrótce po operacji wycięcia gruczolaka przysadki (prolactinoma) z dostępu przezklinowego. W obszarze dotkniętym bólem nie stwierdzano parestezji ani zmian troficznych, występowała natomiast niewielka alodynia. U pacjenta nie obserwowano zaburzenia czucia w zakresie nerwu trójdzielnego ani cech urazu głowy. Stwierdzono korzystną reakcję na leczenie gabapentyną.

Lekarze powinni być świadomi możliwości występowania monetowego bólu głowy w okresie pooperacyjnym; ból poddaje się leczeniu. Spostrzeżenia dokonane u opisywanego pacjenta potwierdzają teorię o dwoistym mechanizmie monetowego bólu głowy i wskazują na ośrodkowy monetowy ból głowy jako formę bólu rzutowanego.

Słowa kluczowe: monetowy ból głowy, pooperacyjny ból głowy, prolactinoma, operacja z dostępu przezklinowego.

Correspondence address: Dr. Wei-Hsi Chen, Department of Neurology, Kaohsiung Chang Gung Memorial Hospital, 123 Ta Pei Road, Niao Sung District, Kaohsiung City 833, Taiwan, phone: 886-7-731-7123 ext. 3399, fax: 886-7-311-2516, e-mail: brainhemostasis@yahoo.com Received: 9.05.2012; accepted: 18.12.2012 


\section{Introduction}

Nummular headache (NH) is a newly categorized primary headache syndrome first reported in 2002 [1]. The incidence is estimated to be $6.4 / 100,000 /$ year. It is characterized by a consistent location, size and shape of the painful area with a clear margin distinct from other primary headache syndromes in each attack [2]. Currently, $\mathrm{NH}$ is categorized under the title of 'cranial neuralgia and central causes of pain' [2], reflecting that the etiopathogenesis is still unknown although intracranial lesions or previous head injury has been found in a few $\mathrm{NH}$ patients. Herein, we report a patient who suffered $\mathrm{NH}$ after trans-sphenoidal surgery (TSS) for recurrent prolactinoma. We present the findings in our patient in order to alert physicians to recognize postoperative $\mathrm{NH}$, which is amenable to treatment, and also suggest a referred pain-based mechanism for $\mathrm{NH}$.

\section{Case report}

A 52-year-old man, who had had hypertension for 1 year, was sent to emergency service due to a sudden onset of severe throbbing headache, vomiting, reduced visual acuity, and confusion. Head magnetic resonance imaging (MRI) revealed a mass with central hemorrhage located at the sellar and suprasellar region (Fig. 1A). A decrease of blood corticotropin to $4.51 \mathrm{pg} / \mathrm{mL}$ (refe- rence range: 9-52 $\mathrm{pg} / \mathrm{mL}$ ), cortisol to $3.74 \mu \mathrm{g} / \mathrm{dL}$ (reference range: $9-23 \mu \mathrm{g} / \mathrm{dL}$ ), thyrotropin to $1.31 \mu \mathrm{IU} / \mathrm{mL}$ (reference range: $0.25-4.0 \mu \mathrm{IU} / \mathrm{mL}$ ) as well as an increase of prolactin level to $26.1 \mathrm{ng} / \mathrm{mL}$ (reference range: $2.9-17.1 \mathrm{ng} / \mathrm{mL}$ ) were detected. Otherwise, other laboratory tests, electrocardiogram and chest radiography did not reveal remarkable abnormality. Endonasal TSS was performed, and microscopy of pituitary tissue showed sheets of polygonal cells with multifocal hemorrhage. Immunochemical staining disclosed dense staining of prolactin. Prolactinoma with hemorrhagic apoplexy was established. The patient rapidly regained consciousness after surgery. Although the headache subsided and visual acuity also improved, cortisone was administered due to hypopituitarism. Bromocriptine was additionally prescribed for prolactinoma. A predominant restriction of the bitemporal visual field was detected after surgery.

The patient consulted our service about 4 years after the first operation due to a new onset of headache, which was compatible with migraine without aura. He responded well to flunarizine, which was discontinued 6 months later without any recurrence of migraine afterwards.

The patient received endonasal TSS twice at 5 and 6 years later due to a recurrence of binocular diplopia and rapid deterioration of visual acuity and restriction of the visual field. The pathology was still the prolac-
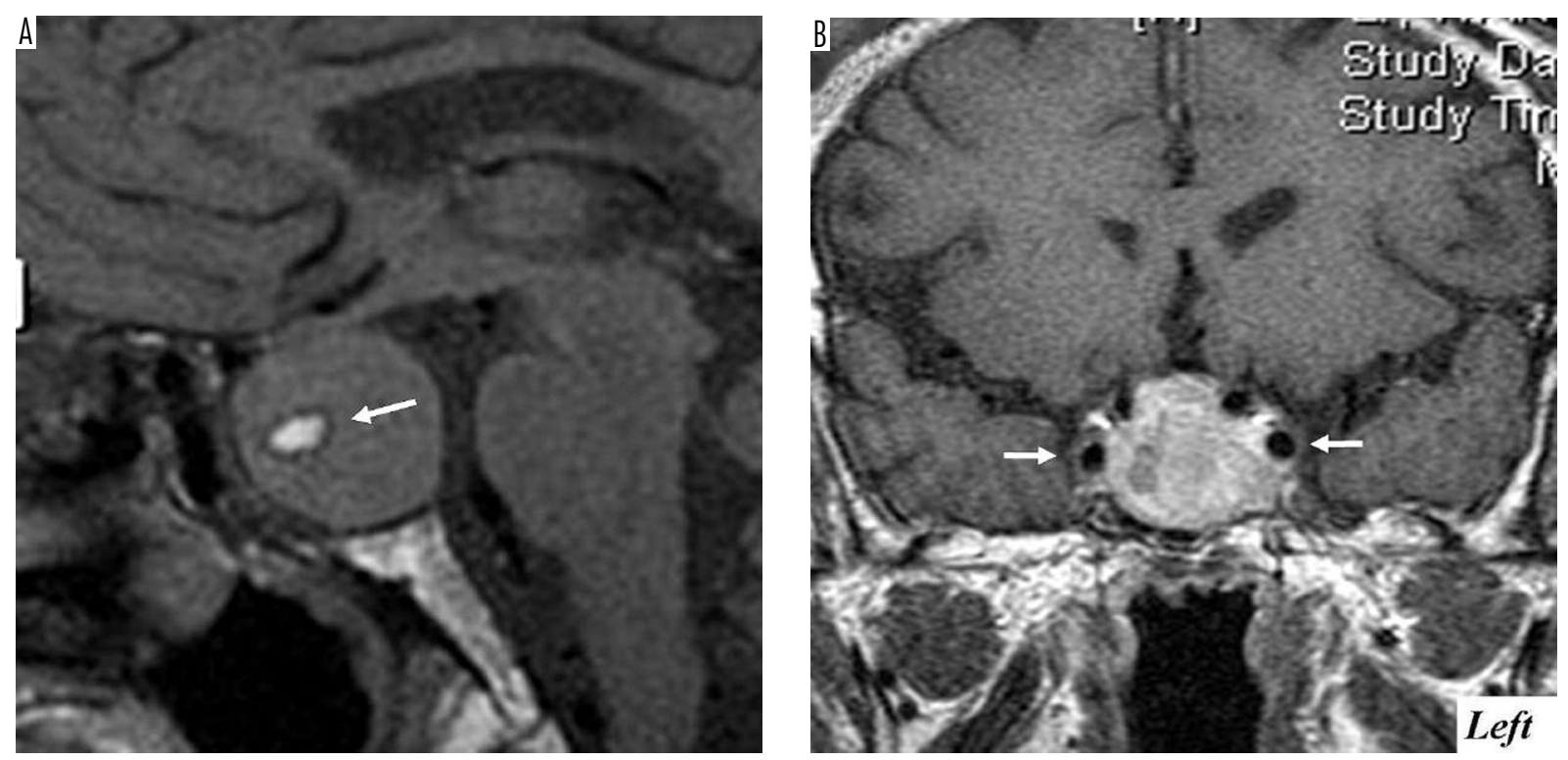

Fig. 1. The head MRI at initial presentation reveals a lesion located at the sellar and parasellar region. This lesion extends into the cavernous sinus at both sides (arrow). A high signal intensity in Tl-weighted image (arrow) within the lesion which is compatible with acute hemorrhage is disclosed (A). Hemorrhagic apoplexy is inferred. Microscopy identifies the prolactinoma. When nummular headache had occurred, the size of prolactinoma did not increase in comparison with the previous imaging (B) 
tinoma. About one week after the operation, however, the patient began to notice a new headache and consulted our service 3 months later again because of increasing severity of pain. The patient described his headache as confined to the left parietal area and vertex with a size of $4 \times 4.5 \mathrm{~cm}$ with an oval shape and an impressively clear boundary of the painful area. The pain cycled with 1-2-week relapses and 2-3-week remissions. It was piercing and electric in nature, paroxysmal, occurred spontaneously, peaked within 1 to 3 minutes, persisted and then subsided within minutes to several hours, and was moderate in intensity. On some occasions, the pain might persist for more than one day. Headache might occur 1 to 3 times within a day. During a painful attack, stretching of hairs or touching the scalp within the painful area would greatly aggravate the intensity of pain. There was no aura, or associated orofacial pain or paresthesia, dysautonomia or other symptoms during an attack. Clinically, NH was suspected. The head MRI did not show significant enlargement of the prolactinoma (Fig. 1B). Laboratory tests showed no abnormal findings, except for fluctuation of blood prolactin level between 9.0 and $22.1 \mathrm{ng} / \mathrm{mL}$, which was lower than before.

After informed consent, gabapentin $100 \mathrm{mg} /$ day was administered. According to the patient, pain was reduced by $10 \%$ after one week and by $30 \%$ after two weeks of treatment. When gabapentin was increased to $300 \mathrm{mg} /$ day, the patient acknowledged a complete recovery of NH. Gabapentin was gradually tapered and discontinued 7 months later. The patient underwent his fourth operation one month after discontinuation of gabapentin but has not had a recurrence of $\mathrm{NH}$ for two years.

\section{Discussion}

Currently, there are two theories for NH. The peripheral theory of epicranial neuralgia in $\mathrm{NH}$ is greatly supported by the prevalence of static/dynamic mechanical allodynia, sensory change, or focal trophic change within the painful area in a host of patients [1]. On the other hand, the central theory is encouraged by concomitant intracranial lesions in a few patients [3-5] and a rapid reverse of pain after removal of the responsible intracranial tumor [5]. Additionally, central sensitization is also able to induce allodynia and paresthesia mimicking peripheral origin of neuropathy [6]. Although multiple head stabilizations in repetitive TSS may raise the question of mechanical damage of the epicranial nerve, an episodic painful attack and an absence of objective sensory change within the painful area do not support a persistent epicranial neuropathy in our patient.

There are two cases of post-TSS NH reported previously $[3,7]$. Including ours, they shared an identical painful area at the vertex, which is the common site of referred pain originating from sellar or parasellar involvement. It raises the question whether the pain in our patient is only a post-craniotomy headache similar to other TSS patients. Factually, the pain in our patient is distinct from the classic referred pain occurring in cases of TSS or pituitary/rhinosinusal involvement due to the consistent shape and size of painful area with a clear boundary from surrounding scalp, and a sharp feeling of piercing and electric pain. Therefore, referred pain is, at least, one reasonable mechanism responsible for central $\mathrm{NH}$.

In fact, the intracranial lesions in previous central $\mathrm{NH}$ patients were exclusively located at the ipsilateral juxtameninges [3-5]. If so, central NH is reasonably rationalized by a form of referral pain from a tear of a pain-sensitive structure such as meninges [3-5] in TSS or other brain surgery $[3,7]$. However, its rarity in postoperative headache or traumatic brain injury cannot be explained only by an underestimation in current. Our patient received four TSS. A consequent occurrence of migraine and $\mathrm{NH}$ after TSS may suggest that these two headache disorders share some comparable bases of mechanism. A pre-existing lower threshold of pain and neurohormonal modulation of pain response [8], superimposed by TSS, may co-operatively trigger $\mathrm{NH}$ occurrence in our patient as seen in migraine.

In conclusion, we report a patient who experienced nummular headache after TSS. Although TSS-related $\mathrm{NH}$ is empirically uncommon in clinical practice, physicians should recognize the character of $\mathrm{NH}$ in which the treatment and prognosis are different from classic postoperative headache. The findings in our patient support the central theory of pain for $\mathrm{NH}$ and also a dual mechanism for $\mathrm{NH}$.

\section{Disclosure}

Authors report no conflict of interest.

\section{References}

1. Pareja J.A., Caminero A.B., Serra J., et al. Nummular headache: a coin-shaped cephalgia. Neurology 2002; 58: 1678-1679.

2. Headache Classification Subcommittee of the International Headache Society. The International Classification of Headache Disorders. Cephalalgia 2004; 24 (Suppl 1): 1-149. 
3. Alvaro L.C., García J.M., Areitio E. Nummular headache: a series with symptomatic and primary cases. Cephalalgia 2008; 29: 379-383.

4. Guillem A., Barriga FJ., Giménez-Roldán S. Nummular headache associated to arachnoid cysts. J Headache Pain 2009; 10: 215-217.

5. Guillem A., Barriga FJ., Giménez-Roldán S. Nummular headache secondary to an intracranial mass lesion. Cephalalgia 2007; 27: 943-944.

6. Latremoliere A., Woolf C.J. Central sensitization: a generator of pain hypersensitivity by central neural plasticity. J Pain 2009; 10: 895-926.

7. Grosberg B.M., Pavlovic J., Robbins M.S., et al. Posttraumatic and postsurgical nummular headache. Neurology 2010; 74 (Suppl 2): A322.

8. Levy M.J. The association of pituitary tumors and headache. Curr Neurol Neurosci Rep 2011; 11: 164-170. 